RESEARCH REPORT NO. 182

\title{
Analysing Institutional Set-up of Forest Management in Pakistan
}

\author{
Lubna Hasan \\ RESEARCH ECONOMIST, \\ Pakistan Institute of Development Economics, Islamabad
}

\begin{abstract}
Acknowledgements: This study is based on the author's unpublished MA Thesis entitled "From Conflict to Cooperation-The Need for a Change in the Institutional Set-up of Forest Management in Pakistan", which was completed at the Institute of Social Studies (ISS), The Hague. The author wishes to thank Mr Guillermo Lathrop and Mr Joao Guimaraes of the ISS for their academic guidance and help. A part of this study was presented at the PIDE Seminar Series in May, 2000. The author is grateful to Dr Rehana Siddiqui for her valuable comments on the paper. Comments from other seminar participants were also useful. Thanks are also due to Dr A. R. Kemal and Dr G. M. Arif for their encouragement.
\end{abstract}




\section{INTRODUCTION}

Pakistan has 4.2 million ha covered by forests, which is equivalent to 4.8 percent of the total land area. Most of these forests are found in the northern part of the country ( 40 percent in the North West Frontier Province, 15.7 percent in the Northern Areas, and 6.5 percent in the AJK). This study will focus on the natural hill forests found in the northern region of Pakistan, particularly the North Western Frontier Province (NWFP).

The total forest cover ( 4.8 percent) is low when compared with other parts of the world, 27 percent for the developed countries and 26 percent for the developing countries. Per capita forest cover presents a gloomier picture. Pakistan has only 0.03 ha of forest per capita while corresponding figures for the developed and the developing countries are 1.07 and 0.50 respectively. With a population growth rate of 2.6 percent, forest per capita is declining in Pakistan.

These forests are not enough to meet the nation's demand of wood and wood based products. In 1998, the wood consumption in Pakistan was 33,018 thousand cubic metres. Total wood produced was only 350 thousand cubic metres [Pakistan (1998)]. This resource scarcity puts a burden on the foreign exchequer. In 1998-99, Pakistan imported Rs 8499.3 million worth of wood and wood products [Paksitan (2000)]. Its total exports of wood and wood products stood at mere Rs 381.4 million.

Pakistan has faced significantly high rates of deforestation in the past. According to one estimate [WRI and IIED (1988)], the forest area of Pakistan decreased from 141530 square $\mathrm{km}$ in 1880 to 67310 in 1980; a decrease of 52 percent in one hundred years. During the 1970's, the study estimates an annual decrease of 1.5 percent per year [Vin Dijk and Hussein (1994)]. Estimates of contemporary deforestation are varied. Pakistan (1992c) reported that some 7000-9000 ha of forests were lost each year. Khattak (1994) puts this estimate at 10,000 ha annually. Since these reports came out in early nineties, these estimates cannot be held true for the nineties. FAO (1998) provides the most recent estimate of annual deforestation. It reported that between 1990-95 Pakistan experienced deforestation at a rate of 1.1 percent (55000 ha) annually. This presents a rather grim picture for the future prospects of the sector. In fact,

\footnotetext{
${ }^{1}$ The forests of NWFP are distributed over the Himalayas in the Hazara Civil Division, and the Hindu Kush in the Malakand Civil Division.

${ }^{2}$ Forest cover estimate for Pakistan is taken from Forestry Sector Master Plan (1992). Figures for the developed and for developing countries are taken from FAO (1995).

${ }^{3}$ Estimates of deforestation rates are very sketchy. In most cases these are mere guesstimates.

${ }^{4}$ This, however, should be taken with a grain of salt since this period corresponds with timber ban, which was imposed in 1992.
} 
doubts have been raised that if nothing is done to check this process the remaining forests will soon disappear [Knudsen (1996) and Khattak (1994)]. This prompts one to study the Institutions of property governing the use of forest resources, the purpose of which is to safeguard resources from overexploitation.

Property institutions and their role in shaping resource use patterns has only recently begun to be studied. The manner in which people use environmental resources depends on the property rights governing those resources [Tietenberg (1994), p. 31]. It is argued that since human beings interact with their environment through institutions of property, and since much of the environmental deterioration is attributed to human activities, roots of environmental problems are to be traced to inadequate and ill-defined property institutions [Hanna and Munasinghe (1995)].

These property institutions are a part of over all institutions of a society [North (1990)]. Institutions are a set of rules that govern and constrain human interaction. The role of institutions in determining economic performance has been widely studied. Since institutions define the framework within which human interactions take place, and hence structure human behaviour, our environment, and more specifically, the resource use pattern is influenced by it. We develop these arguments further to construct our conceptual framework, which is the next section of this study. In third section we use this framework to analyse institutional set up for forest management in Pakistan. The fourth section concludes this analysis. The fifth section gives policy recommendations.

\section{THE CONCEPTUAL FRAMEWORK}

The first part of this section discusses institutions. This is a general discussion. The purpose is to get useful insights into the nature of institutions. From there we move on to discuss Property institutions and related concepts. Property is defined as a relation among individuals, which arise from the

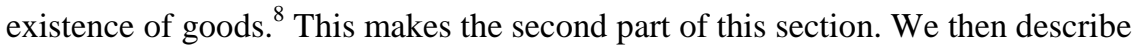
forests as common pool resources. In the last part of the section we draw upon our previous discussion to come up with a set of minimum basic conditions that are important for an optimal utilisation of the resource. This will make our conceptual framework.

${ }^{5} \mathrm{Hanna}$ and Munasinghe write that most of the environmental problems can be seen as problems of "incomplete, inconsistent, or unenforced property rights regimes" [Hanna and Munasinghe (1995), p. 15].

${ }^{6}$ This definition of institutions is adopted from North (1990).

${ }^{7}$ This concept is explored by the NIE School of Thought. According to this school of thought institutions are important in determining the economic outcomes because they, together with other economic constraints, define the opportunity (or choice) set of individuals. [See Harris $e t$ al. (1995); North (1990, 1991); Ostrom (1990); Eggertsson (1990)].

${ }^{8}$ Pejovich (1990). See below for further elaboration of the concept. 


\section{Defining Institutions and Their Components}

The idea that institutions are important in the functioning of an economy is not new. The New Institutional Economics (NIE) school of thought has made considerable advances on this account, and has earned itself a prominent position in the realm of economics. The main postulate of NIE is that institutions, broadly defined to means rules and constraints that provide a framework for human interaction affect economic outcomes.

North (1990) defines institutions as humanly devised constraints that shape and guide human interactions. They reduce uncertainty in everyday life by providing a structure to human interaction and behaviour [North (1990), p. 3]. Institutions include any kind of constraints/rules that human beings devise to shape interactions: both formal and informal.

Formal constraints are the rules devised by human beings to facilitate exchange. These include political (and judicial) rules, economic rules and contracts. Of our interest here are the economic rules, which define property rights. Property right is the right to use, earn income from and alienate a resource [Barzel (1989)].

Informal constraints are the norms, convention, and code of ethics that societies evolve over time. These constraints are more pervasive than formal rules [North (1990), p. 36]. These informal constraints are socially transmitted information and are a part of the culture. They do not change immediately in reaction to changes in the formal rules. The resultant tension between changed formal rules and the persisting informal rules has implications for the economic outcomes (ibid: 37 ).

A rule serves no purpose if it cannot be enforced, so enforcement mechanism is an integral part of any institution. Rules are not always selfenforcing, and hence their enforcement cannot be taken for granted. Enforcement is not a problem when exchange parties gain from cooperating. It becomes a problem when benefits from shirking become quite substantial. "There are two reasons why enforcement can be imperfect. The first is the cost of measuring the multiple margins that constitute performance. The second rests in the fact that enforcement is undertaken by the agents whose own utility functions influence outcomes" [North (1990), p. 54].

Enforcement mechanism requires (1) ways to ensure that rules are observed, and (2) sanctions against violations. The costliness of ascertaining violations and the severity of punishment are considered to be an essential part of the functioning of institutions (ibid: 4). North argues that ultimately those institutions are required that can use threat of coercion to enforce agreements, and the state is the only authority that can exercise this threat of coercion.

\footnotetext{
${ }^{9}$ See Nubli and Nugent (1989) for a review of literature on New Institutional Economics. Also see Harriss, Hunter and Lewis (eds) (1995).
} 
Rawls defines institutions as a "public system of rules that specify certain actions as permissible, other as forbidden, and provide for certain penalties and defences when violation occur" [Runge (1984), p. 807]. Basically, institutions provide a set of constraints which govern behavioural relations among individuals and groups [Nabli and Nugent (1989), p. 1335]. We focus upon this theme in our discussion.

Institutions perform a coordinating function in the society. Rules define what individuals are allowed to do and what they can expect from fellow human beings. Even though they may at times produce conflicts, rules "reduce the chances for conflict because they reduce the total amount of ambiguity for those concerned by defining specific rather than universalic claims and obligations. It becomes possible to order one's life with a set of priority regarded as legitimate [Colson (1974) and North (1990), p. 38].

According to North the major function of institutions in a society is to reduce uncertainty by giving a stable structure to human interaction. Uncertainty comes from incomplete information about the behaviour of other individuals in the process of human interaction. Even if complete information was available, individuals have limited mental capacity to process, organise and utilise information-bounded rationality. This bounded rationality, combined with uncertainty in deciphering the environment, imply the need to develop the regularised pattern of human interactions and results in evolution of rules and procedures that simplify the process.

Institutions facilitate exchange by reducing costs of transaction. Transaction costs consist of cost of measurement, the cost of measuring the valuable attributes of what is being exchanged, and the cost of enforcement, the cost of protecting rights and policing and enforcing agreements. ${ }_{\text {North (1990) }}$ argues, "these measurement and enforcement cost are the sources of social, political and economic institutions" [North (1990), p. 27].

Runge (1984) argues "institutions channel the behaviour of people with respect to each other and their belongings, providing assurance by setting the rules of the game. They increase the value of a stream of benefits associated with economic activity by coordinating behaviour" Institutions perform the function of reducing uncertainty of users by defining and stabilising their expectations. It is necessary to make one qualification to this statement. Institutions are not always growth enhancing. They have the potential to increase output from economic

\footnotetext{
${ }^{10}$ Commodities, services and performance of individuals have many attributes and their level vary from one specimen to another. The measurement of these levels is too costly to be comprehensive or fully accurate. The information cost in ascertaining the level of attribute yields measurement costs.

${ }^{11}$ Enforcement cost arises from incomplete information. Because we do not know the attributes of a good or service or all characteristics of the performance of an agent we have to devote costly resources to try to measure and monitor them.
} 
activity, i.e., if appropriate rules are devised and enforced. In most third world countries institutions are not efficient. They are not even meant to be efficient. Rather "they are created to serve the interests of those with the bargaining power to devise new rules" [North (1990), p. 16]. With this we conclude our discussion on institutions. Later, these concepts will be used to develop the analytical framework.

So far we have talked about institutions in general and since property institutions are a subset of over all institutions much of what had been said so far applies to them. Still we have to dig deep into the concept to see what does the concept of property really entail, and what important consideration have to be kept in mind in setting up a proper institutional set up.

\section{Property-Theoretical Considerations}

Property is a relation that defines an individual vis-à-vis all other individuals with relation to an object [Pejovich (1990)]. In legal talks, property is not things but rights, rights in or to things [Macpherson (1978), p. 2].

An important point to notice is the distinction between property and a mere physical possession of an object. Green (1885) explains that "property not only implies a permanent possession of something, or a possession that can be given up with the good will of the possessor, but also a possession recognised as a right" [Macpherson (1978), p. 103]. The concept that we want to emphasise here is that of social recognition and acceptance. Macpherson (1978) goes further in explaining the concept, for him "to have a property is to have a right in the sense of an enforceable claim to some use or benefits of something .... claim that will be enforced by the society or the state, by custom or convention or law" [Macpherson (1978), p. 3]. So, property is not just a claim, it is a claim that is accepted and endorsed by the society at large.

The concept of enforceability needs some elaboration. Defining property as an enforceable claim implies that there be someone to enforce it, the only body that is extensive enough to do that is the society itself, or its specialised organisation- the state [Macpherson (1978), p. 4]. Enforceability does not imply that the right rests on nothing but a threat of force. On the contrary, "the threat of force is invoked only as an instrument that is thought to be necessary to guarantee a right"(ibid. p. 3). The social recognition of the claim is very important.

\section{Property System}

Property system is a system of rules governing access to and control over resources [Waldron (1988), p. 38]. Property systems are central to an economic system as they solve problem of allocation of resources. Bromley defines property institutions are public system of rule specifying permissible and forbidden actions in relation to ownership, use rights, responsibilities and obligations of 
individuals and groups [Runge (1984), p. 807]. Property rights are relations among individuals that arise from the existence of scarce goods and pertain to their use. They specify the norms of behaviour with respect to economic goods that all person must observe in their interaction with other people or bear the penalty cost of non-observance [Pejovich (1990)].

Honore (1961) has elucidated some common features, which he calls 'the standard incidents', of the concept of ownership. ${ }^{2}$ He suggests that "the owner of an object $X$ will have (1) a right to the possession of X; (2) a right to use X; (3) a right to manage $X$; (4) a right to income that can be derived by permitting others to use $\mathrm{X}$; (5) a right to the capital value of $\mathrm{X}$; (6) a right to security against the expropriation of $X ;(7)$ a power to transmit $X$ by sale, gift or bequest; (8) the lack of any term on the possession of any of these rights; (9) a duty to refrain from using $\mathrm{X}$ in a way that harms others; (10) a liability that certain judgments against him may be executed on X" [Waldron (1988, p. 49)]. It is this bundle of rights, duties and liabilities that constitute a structure of ownership.

\section{Economic Approach to Property}

Economics is about making the best possible use of scarce resources. Since property rights determine the conditions of access to and control of these scarce resources, a set of particular property right has impact on the economic performance of the economy. This point is advocated by the so-called 'Property Rights School'. They stress that a well-defined structure of property rights induces efficiency in the use of resources. ${ }^{14}$ Before we define what is exactly meant by 'well defined structure', we give how property is conceived by economists.

Economists' definition of the term property differs slightly from a legal definition. For them, property is a claim to a stream of benefits coming from a resource. Resources are something that offers benefits to human beings. Reeve (1986) describes resources as objects of want: something people wish for because it provides satisfaction, either direct or indirect, to them. An object becomes a resource when people develop ability to command that benefit stream [Dani, Gibbs, and Bromley (1987), p. 14].

What are the features of a well-defined property rights structure? Posner (1973) identifies three characteristics of an efficient set of property rights: "it is

\footnotetext{
${ }^{12}$ They are not the 'essential features' of each and every society; rather they may be present in different societies in different combinations such that some features may be more prominent in one society than in the others, some may even be missing in a society.

${ }^{13}$ The concept of ownership is usually meant to denote exclusive (private) ownership. Exclusive ownership implies the right to exclude non-owners.

${ }^{14}$ Demsetz (1967) is one of the pioneering works on this field. Other prominent supporters of this view include Posner (1973); Pejovich (1990); Tidsell (1992); Tietenberg (1992, 1994). Posner (1973) argues that the function of property rights is to create a structure of incentives to use resources efficiently [Reeve (1986), p. 23].
} 
universal, in the sense that all resources are either owned, or capable of being owned, by someone; it is exclusive, in the sense that other persons may be excluded from enjoyment of the object of the property right; and the property rights are themselves transferable" [Reeve (1986), p. 24].

Why would this structure induce efficiency? The argument goes as follows: The first condition of universality implies that all things should be owned. Ownership creates interest in the thing owned. In fact Honore (1961) defines ownership as "the greatest possible interes 15 in a thing which a mature system of law recognises" [Reeve (1986), p. 18]. What is this interest? Nozick states that the rules of property determine for each object which individuals are entitles to realise which of the constrained set of options socially available with respect to that object [c.f. Waldron (1988), p. 32]. So if an object yields benefits then the owner of the object is entitled to receive those benefits. In other words, property rights channel benefits associated with an object to the right holder and this creates an interest.

The second condition is of exclusivity. Put simply, exclusivity implies exclusive ownership and a right to exclude non-owners. Pejovich (1990) explains that the exclusivity of ownership means that the owner has the right to choose what to do with his asset, how to use it, and who is to be given access to it. He has a right to exclude non-owners from exercising any of these rights. The exclusivity creates a link between one's right to choose how to use the asset and bearing the consequences of that choice. Since the owner of the asset is the only person who will receive benefits from that decision, he will have an incentive to put his asset to the highest value use.

This brings in the basic argument of the economic approach to property rights which is that the costs and benefits of a person's activities should rebound on him, and only on him. Inefficiencies in resource use occur when a person, a decision maker, does not bear the entire consequences of his action. This situation is depicted as one involving externality. ${ }^{16}$ Demsetz (1967) argues that a well-defined structure of property rights will increase efficiency in resource use by internalising these externalities. Property rights should be structured such that the harmful or beneficial effects of a person's activities are brought to bear on him rather than on other persons [Reeve (1986), p. 26].

\footnotetext{
${ }^{15}$ The greatest possible interest is used to denote that ownership is not absolute; it is constrained by social restrictions. Honore uses the example of umbrella to make his point, an owner of an umbrella may use it for his convenience but he cannot use it to poke other people with it. The ownership rights of the umbrella owner are not unlimited.

16 "Externality exists when the welfare of some agent A depends directly on his activities and on activities under the control of some other agent B" [Tietenberg (1992), p. 52)]. The agent B does not bear the entire cost (negative externality) or reap the entire benefit (positive externality) of the action. In the case of negative externality, private cost (of the action) to the agent $\mathrm{B}$ will be less than the social cost (cost to the society) and economic activity, e.g., production will take place at level greater than optimum. In the case of positive externality, good will be under supplied.
} 
Transferability is another condition. It means that the owner has the right to transfer all or part of his rights to another person in a mutually agreed upon exchange. Transferability provides incentive to move resources from less productive to more productive opportunities [Pejovich (1990), p. 29].

Tietenberg (1992) lists one more condition- enforceability, and quite rightly so. Enforceability means security from involuntary seizure or encroachment by others. What Honore (1961) calls a right to security against the expropriation of the asset. Reeve (1986) discusses that interest in a resource is conceptually linked to the means available to protect it. A claim to a resource is taken to be good against and legally guaranteed against any rival claims. Protection may be conceived in two ways- de facto and de jure; de jure protection refers to written laws and de facto refers to actual practice of it. Protection also involves consideration of penalties. The size of penalty determines the degree of protection that the property enjoys.

Together these four conditions determine an efficient structure of property rights. It is argued that the only system that carries these characteristics is the system of private property.

\section{Forests as Common Pool Resources}

Technically speaking, natural forests share their attributes with Common Pool Resources. Ostrom and Gardner (1993) define Common Pool Resources as natural or man made resources where exclusion is difficult and yield is subtractable. As such they share their first attribute with pure public goods and the second attribute with pure private good. The first attribute, difficulty of exclusion, results from factors such as cost of parcelling and fencing the resource and the cost of designing and enforcing property rights to exclude access to the resource. It is this attribute of CPR that makes them prone to free riding by others. The second attribute of subtractability means that resource unit that one person appropriates from the resource is not available to others [Ostrom and Gardner (1993), p. 93]. These two attributes collectively make common pool resources vulnerable to extinction, thus

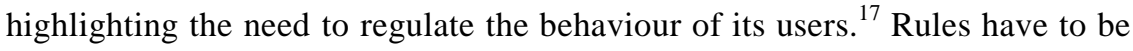
set for a sustainable level of exploitation of the resource; some kind of enforcement mechanism is needed as well. This function is provided by the resource regime.

\footnotetext{
${ }^{17}$ The notion of resource management stems from their scarcity, if they were in unlimited supply the need may not have arisen. This applies to all resources and not just common pool resource.

${ }^{18} \mathrm{~A}$ resource regime is a structure of rights and duties characterizing the relationship of individuals to one another with respect to that particular resource [Bromley and Cernea (1989), p. 5].
} 


\section{Basic Conditions for a Proper Institutional Set-up}

Macpherson (1978) writes that institutions are man made, and are created with some objective. ${ }^{9}$ We make a qualification to this statement and say that although institutions evolve over time, and hence cannot be described results of human action; formal rules still are a result of purposive human actions. So we make amendment to the above statement and say that formal rules are man made are made with some objective in mind. These objectives determine the shape of the institution.

We draw a logical implication from this that if some objective is set, and a rule is made accordingly, then proper institutional arrangements must also be made to ensure that the rule is observed, which should eventually help secure the objective. In this part we will explore this point. To put it clear, if the government has outlined an objective for the forestry sector than it must also establish an appropriate institutional set up to achieve that objective. We will make a normative criterion, elaborating the conditions that we think are necessary, for this we draw upon the discussion so far. Before that we summarise what has been said so far.

In the first part of the chapter we talked about institutions. Institutions were defined as rules and constraints that shape human behaviour; as such they provide structure to human interaction. We argued for the "New Institutional" point of view that institutions have an important implication for economic performance. This is so because they have the potential ${ }^{20}$ to increase the flow of benefits from economic activity.

We talked about the important feature of institutions, relying mainly on the work of North (1990). Using his theory we said that the function of institutions is to coordinate behaviour. As Runge (1984) said, institutions set rules of the game so that each individual knows what actions he is allowed to take and what not, what he is expected to do and what he can expect from other fellow beings. To a large extent these rules should eliminate conflict of interest.

We elaborated on the idea that rules not only include formal rules but also informal rules. Formal rules are the result of decision taken by human beings. Informal rules are codes of conduct that evolve over time. They are more pervasive and immune to abrupt changes. As a result, they play an important role in structuring interaction. North (1990) argues that ideally formal rules should be devised so as to make the informal rules more effective.

\footnotetext{
19،Institution is man-made, it is assumed to have been made, and to be kept up, for some purpose: either to serve some supposed essentially human needs, which would determine what the institution is; or to meet the wants of the classes which have made it what it is" [Macpherson (1978), p. 1].

${ }^{20} \mathrm{We}$ use the word potential because all institutions are not growth enhancing. The relation between institutions and economic performance is not unique. Institutions can retard performance if they do not function properly.
} 
A rule serves no purpose if it cannot be enforced. Enforcement can come from two sides: (1) voluntary acceptance, and (2) enforcement by an external authority, either society or the state. In the case of voluntary acceptance enforcement poses little or no problem. In the second case it may be a problem, or it may not. Enforcement will not be a problem if the rule earns social acceptance, but if does not then enforcement can be difficult and costly. North (1990) suggests that rules should be devised with compliance cost in mind. Enforcement has two components: (1) ways to ascertain that violation has occurred; (2) sanctions and punishment against that. Effective enforcement requires both, a mechanism to detect violation, and proper sanction to deter anyone from violating the rule. These rules and constraints and enforcement are the essential feature of institutions.

If the state sets some policy objectives for itself, then it must ensure that a proper Institutional set up is in place to accomplish those objectives. In other words, rules that are devised must structure human behaviour such that the objective is secured. These rules must be enforceable. We can put these conditions as following:

1. Appropriate rules are devised; appropriate in the sense that if they are respected, they will secure the objective. These rules must be appropriate from the point of view of social set up as well. That is, formal and informal constraints must not stand in contrast to each other. This is important because eventually the purpose of institutions is to coordinate behaviour, and this second condition is necessary to secure that.

2. Rules and constraints are enforceable; enforcement has two components; (1) voluntary enforcement, i.e., individual accepts the rule as morally right and observes it, (2) enforcement by an external agency which includes (a) social acceptance, i.e., society as a whole accepts the rule and then uses social pressure to make individuals observe, and (b) enforcement by law, where threat of law (or coercive force) is used to enforce the rule. This still does not mean exercise of this force in the real sense of the word; just the threat that in case rule is not observed some legal action will be taken.

3. Proper enforcement mechanism exists, both de jure and de facto; it must include,

- A mechanism to detect that violation of the rule;

- Penalties against violations. These should be sufficient enough to discourage violations;

- A mechanism to impose penalties. 
This enforcement mechanism is necessary to minimise chances of violations. A simple threat of law will not work if people know that they may not be found breaking the rule, so first condition is necessary for this reason. Second condition is also important because if penalties are small, they may not deter people if benefits of their actions outweigh this cost.

In the discussion on property, it was defined as an enforceable claim. It is not mere physical possession, neither just a claim, it is a claim that is accepted and acknowledged by the society. It was said that enforceability does not imply that the right rests on nothing but a threat of force. On the contrary, "the threat of force is invoked only as an instrument that is thought to be necessary to guarantee a right" [Macpherson (1978), p. 3]. The social recognition of the claim is very important. We talked about a 'well defined' property right structure, and that this structure ensures efficiency. We also said that whatever the objective, property rights must be structured accordingly.

"Essential for any property regime is an authority system able to ensure that the expectations of rights holders are met. Compliance, protected and reinforced by an authority system, is a necessary condition for the viability of a property regime" [Bromley and Cernea (1989), p. 17].

Lastly, we talked about common pool resources and that they are characterised by difficulty of exclusion, since problems of exclusion are directly related to the problems of protection, a system of protection is very important for these types of resources. With this in mind we turn attention to the present case and see what are the objectives and whether appropriate rules exist.

The primary objective of all forest policies has been to use forests for the well being of people. This has more to do with the political ideology. For more practical purposes two objectives can be identified:

1. Conserve and protect the forests. This is more primitive than other objective, dating back to the middle of eighteenth century when the British first took control of the forests;

2. Use it pragmatically to meet wood demands of the nation.

Natural forests serve two important purposes: they serve the important function of protecting the watersheds, and as such they have large positive externality; and they are a prime source of timber. The government has outlined following objectives for these forests:

(a) Manage them for the protective service they provide;

(b) Use them to meet timber requirements without harming the resource.

The two objectives can be compatible only if the forest resource is used and managed in such a way that the flow of benefits from them is maximised, in other words they are used as efficiently as possible. What conditions are then 
necessary to achieve that? We draw upon the previous discussion. We have said that if the objective is to maximise the flow of benefit from an economic activity then it is essential that the institutions are efficient. Our discussion about property has established that to use resources efficiently, a well-defined structure of property rights must be present. From this discussion and from the objectives given above we must identify a structure that serves both objectives simultaneously. We elaborate on it now.

(1) The first important condition is that forests are owned. We have said that ownership creates an interest in the resource. In the case of private ownership this interest is personal because the owner can then receive the benefits. In the case of state ownership the state has to look after the welfare of the community/people.

(2) This is related to the first condition, it is important point that the ownership be socially accepted as morally right. Formal property right is compatible with the informal property rights, and there is no conflict of interest as a result of this property rule.

(3) Ownership is exclusive. The owner has the right to make decision about the resource and can exclude others from this process. The decision involves how to use the resource, how to manage it, and whom to give access to it. With regards to these latter points, it is important that:

(a) Management system supports both objectives; that is of sustainability, and of protective service;

(b) It must internalise the externality. In case of positive externality the good is under supplied; if forests exert a large positive externality in terms of providing a protective service then the property right structure must internalise this externality.

(c) Forests are considered to be for the benefit of people, so a system of ownership must be accompanied by a system of accountability ensuring that forests are being managed for the best interest of the people.

(4) A proper enforcement mechanism for the protection of forests. It was said before that common pool resources are characterised by difficulty of exclusion, and this makes their protection against illegal seizure a problem. Therefore an enforcement mechanism is necessary. We earlier said that this must have two components;

(a) A system of communication to detect that a crime has been committed;

\footnotetext{
${ }^{21}$ Often called 'collective interest'.
} 
(b) A system to impose penalties;

(c) Penalties should outweigh benefits from the crime.

\section{FOREST MANAGEMENT IN PAKISTAN}

In the previous section we developed a framework identifying basic conditions that should be present if government intends to achieve its policy objectives. In this section we use that framework to analyse current resource regime. For that purpose we group those basic conditions under three main headings; (1) ownership structure; (2) Enforcement mechanism; (3) management system.

\section{Ownership Structure}

In Pakistan, forests are held under a variety of ownership arrangements. According to legal classification, forests are divided between public forests (state-owned) and private forests (non-state). These are further divided into subcategories. The main categories of public forests are reserved, and protected. While guzara forests constitute the main part of private forests. ${ }^{2}$ In NWFP, reserved forests ( 97.9 million ha) and guzara forests (48.4 million ha) are found in the Hazara division. Protected forests (57.7 million ha) are mostly situated in Malakand division. 3

Reserved forest is the strictest tenure class in which locals have no rights. The right of passage, water, and grazing are allowed as concessions with government approval. In the protected forest, in addition to these rights, locals are allowed fuelwood collection and timber for their personal needs. They also have 60-80 percent share in the sale proceeds. Guzara forests are private forests held either individually (by families), or jointly (by communities). But these forests are managed by the forest department, except for a short period of time (1981-1992) when they were managed by forest cooperative societies.

\section{Evolution of Property Rights}

This section traces the evolution of property rights in forests. The documented forest history of the subcontinent dates back to the middle of the nineteenth century, about the same time when British advent of India occurred. Not much is known about the pre-colonial pattern of land ownership, except that it was predominantly communal. Singh (1986) estimates at least 80 percent of the total natural resources of India were under some kind of common property.

\footnotetext{
${ }^{22}$ Azhar (1993) labels them as regulated commons. Most of these forests are held jointly by group, but managed by the government except for a short period of time (1981-1992) when these forests were managed by forest cooperative societies.

${ }^{23}$ Area estimates are taken from Annual Development Statistics NWFP (1999), p. 180.
} 
Forests, being no exception, were mostly held as common property by those living close to them [Azhar (1993); Gadgil and Guha (1995); Guha (1993, 1989); Singh (1986)].

Generally, the idea of private property, and as such of private (exclusive) property rights to forests was alien to the local population. Forests were freely available to the locals for use. It does not however imply that they were open access resources. There were customary rights on those forests, in some instances they were recorded (in the wajab-ul-arz; a document maintaining records of the entitlement of individual village households). In most instances, locals were not owners of the resources; rather, they had usufructus rights. ${ }^{24}$ The right of ownership lied with the local rulers, but they never intervened in the exercise of the usufructus rights by the local inhabitants [Azhar (1993); Mumtaz and Nayab (1992); Cernea (1990); Singh (1986)]. Literature also reveals that these resources were used for subsistence living, and commercial exploitation was an absent phenomenon in those days [Guha (1993); Singh (1986)].

After colonisation of the sub-continent, around the middle of the eighteenth century, British started with their land settlement process. The state extended its control over forests through the Indian Forest Act of 1878, and as such nationalised one fifth of India's land area. It enacted legislation 'regulating peasant access by restricting it to areas of forests not deemed commercially profitable' [Guha (1993), p. 85]. Under this legislation, punitive sanctions were introduced against transgressors, and a forest department was set up to police the forests in addition to regulating tree felling in the areas brought under government supervision" [Banuri and Marglin (1993), p. 30].

The most well stocked forests (commercially profitable) were declared as reserved forests, and those that were not well stocked were left for the local population to meet their requirements, these were labelled wastelands. ${ }^{5}$ So initially, the task resulted in the division of forests in two categories: the reserved forests and wastelands/guzara Forests. The reserved forests were almost free of rights of locals. The rights of passage, water use and grazing and fuelwood collection were allowed as a concession. In the guzara forests, in addition to above stated rights, local people were allowed to make use of the forest for liquidation of debts and the education of their children; moreover they could exploit the forests for commercial purposes on payment of a small fee to the government. ${ }^{26}$

\footnotetext{
${ }^{24}$ What Singh (1986) describes as occupancy rights.

${ }^{25}$ In some areas the wastelands were later labelled Guzara forests

${ }^{26}$ This account of customary rights is taken from Azhar (1990). Also see The West Pakistan Forest Manual, Volume 1, Legislation Relating to Forest Administration with Rules made under Forest Acts and Regulations (1963).
} 
The arrangement posed problem; it provoked local people because it had caused infringement of their customary rights. ${ }^{27}$ Locals could no more exercise their rights with same freedom. In the case of reserved forests the infringement was severe, as they could not cut trees any more. For guzara forests they had to seek permission from the government for the exercise of same rights.

\section{Demarcation of Forests}

The next step in the establishment of state's control over forests was a demarcation between reserved and guzara forests. Since the purpose of state control of the forests was to safeguard state forests from misuse by the local population, therefore, a proper demarcation was essential in restricting people's access, defining boundaries beyond which local users (and others) could not go. This, however, could not be accomplished with ease. In fact government's attempts at demarcation were met with protest from the local community as they contested the rights of the government, ${ }^{2}$ and struggled to assert their rights over forestland. Consequently the government failed to demarcate reserved forests [Azhar (1993)].

The government could only accomplish the task by leaving the disputed areas out of the reserve category. It had to constitute another category of forests to accommodate these disputed area, labelled protected forests. ${ }^{\text {.9 }}$ It was decided that demarcation would only occur when nature and extent of rights were thoroughly investigated.

In the protected forests locals were given more rights. In addition to the concession they enjoyed in the reserve forests, the locals had rights to cut timber for their non-commercial needs, subject to prior governmental approval. The government itself retained the rights to trees of spontaneous growth, and carried out large felling operations during this period for the building of local cantonment and the northwest railways [Azhar (1993)]. Such felling in turn fuelled resentment among the right holders because they considered this as an infringement of their rights.

Literature also reveals that Government efforts at demarcation were only half-hearted. Jan (1965) observes that "boundaries pillars ... ultimately

\footnotetext{
${ }^{27}$ Guha (1993) writes that "the abrupt extension of state control sharply conflicted with the customary use of the forest by the local population" and led to protests by the locals [Guha (1993), p. 83-86]

${ }^{28}$ Traditional usufructus rights of these forests lied with the communities, and were recorded in some cases.

${ }^{29}$ Government. Of West Pakistan in one of its report-The Report of the Murree Hills High Powered Commission; Lahore: Government Of West Pakistan, 1958-writes that the protected forest category was constituted because "it was a quicker process involving much less labour for the settlement officer and partly because the forests were burdened with rights which were recorded" [Azhar (1993), p. 126].
} 
disappeared due to lack of subsequent repairs with the result that the demarcation lines remain only on ... map" [Azhar (1993), p. 127). On the state of boundaries in the Murree Kahuta forest division, Bashir (1959) writes that "in several forests ... boundary pillars were found missing and there was no clearly defined boundary line" [ibid, p. 127]. On this Muhammad (1972) later noted, "the reserved and protected forests were not even touched by the settlement officer" [Azhar (1993), p. 127].

As a result of this lack of effort there has been considerable illegal annexation of and encroachment on Guzara and state forests. According to Muhammed (1972) "the forest department was not adequately represented in the current settlement and the settlement officer has shown the encroachment in the reserved and protected forests as nautors ${ }^{\text {in }}$ guzara forests" [Azhar (1993), p. 127].

In conclusion we can say that state control of the forests was never accepted by the local population, particularly in those forests where traditional usufructus rights had existed. This resulted in a conflictual relationship between the government and the locals that has persisted over the years. In the face of local protests, the government had no option but to leave the disputed areas out of the Reserve category. This led to the emergence of another category of forests, called Protected forests, and locals were granted more rights in those forests. More importantly, the disputed state of these forests was recognised and it was decided that the decision would be taken only after a thorough investigation on the legitimacy of claims had been done.

\section{Conflicts, Uncertainties, and Their Impact on Forest Management}

Gadgil and Guha (1995) consider that the most important consequence of the state action was the "intensification of social conflict between the state and its subjects. Throughout the colonial period, popular resistance to state forestry was remarkably sustained and widespread" [Gadgil and Guha (1995), p. 85]. Opposition to forest management was expressed through the violation of forest laws. Constituting a direct challenge to the state to relax its control over the forests [Guha (1993), p. 87].

Cernea (1988b) in an appraisal of the World Bank assisted social forestry project notes that the FD was in open conflict with the majority of population [Cernea (1988b), p. 164]. This feeling of apathy is not one way. Dove (1994) notes that the FD has an attitude of mistrust towards local population and attributes overexploitation of tree products and deforestation of forested area to the 'anti-tree' attitudes of the rural people. Up until recently, state foresters maintained that farmers were not merely the enemies of the forest (i.e., the state forests), but they were also opposed to trees per se" [Dove (1994), p. 107].

\footnotetext{
${ }^{30}$ Nautors refers to breaking of guzara land for private cultivation.
} 
Considerable uncertainties exist in the tenure pattern of Protected forests. These forests were the result of failure of government to demarcate disputed lands. This declaration was used as an interim device to extend legal cover to the disputed forests till the process of settlement can occur. The settlement process is meant to examine the rights and claims of locals in detail in a judicial process. This judicial inquiry should result in acceptance, rejection or commutation on suitable payment of these rights. In latter two cases, the forest can then be declared as Reserved. A protected forest is therefore not a category where forests can remain perpetually.

Pakistan (1992) in its report on the state of forestry in NWFP admits that the disputed status of Protected Forests has affected its management. It writes, "ownership of these forests is often disputed. The ongoing disputes have prevented settlement in the Malakand Division and interfere with proper management of Protected Forests" [Pakistan (1992b), section. 1-3]. government claims that the legal title lies with the government but the locals make competing claims. Most studies on forestry talk of abuse of customary rights [Khattak (1996, 1994); Azhar (1993); Pakistan (1992a), Cernea (1990)].

Khattak (1994) argues that tenurial uncertainties and inequalities are a major cause of forest depletion. He argues "large scale deforestation in the Malakand Agency was caused during the seventies by tenants who considered it inequitable for landlords to claim major benefits from forests even when they were not resident in the area [Khattak (1994), p. 29].

Writing on the current degraded state of Hazara forests, Azhar claims that population pressure does not seem to be an important factor in the degradation of these forests. In 1870 the average household holding was 16 acres, sufficient to meet the household requirements. From this he concludes that it was the "prevailing atmosphere of antipathy towards the government and the forests contributed to the decline of forests". Clearing forest lands to rid them of the state rights seemed logical on part of the right holders to ascertain their claims on these lands" [Azhar (1993), p. 120, emphasis added].

Indeed, excessive felling of trees was triggered by tenurial problems, but there are other dimensions of this problem too. The case of the pilot forestry programme under the Azad Kashmir Hill farming Technical Development Project in Pakistan, co-financed by the World Bank between 1978-83 illustrates

\footnotetext{
${ }^{31}$ This report is a part of a comprehensive 25 year plan for the forestry sector. This plan, (Forestry Sector Master Plan (FSMP) 1992) was prepared with the financial and technical assistance of Asian Development Bank. The FSMP provides policy guidelines for the national development of forestry in Pakistan.

${ }^{32}$ Pakistan (1992a), in fact, holds this abuse of rights as one of the main cause of forest depletion. Khattak (1996) writes "the main cause of forest depletion in NWFP is wood removal by local communities for meeting their domestic needs, and excessive timber removal by the vested interests through licit and illicit means" [Khattak (1996), p. 4].
} 
one more dimension- resistance by the local population to active management by the FD, namely in regeneration and plantation (afforestation).

This project aimed at artificial regeneration by planting trees on communal lands. Cernea (1988b) writes, "the small farmers hesitated to accept project planting on their lands. They were fearful of losing possession or control over their land to the government once it was planted by the FD, or being deprived of their rights to collect fodder and graze their cattle. Most of the farmers interviewed indicated that they might offer small plots for project planting, provided they could be convinced that the FD would not alienate their lands and that they would be able to cut grass for their cattle" [Cernea (1988b), p. 170]. "In contrast, large landowners, being confident of their political power, did not regard tree planting by the FD as a threat to their ownership of land and trees" [ibid, p. 170].

A joint study by the Government of Pakistan and the Dutch Government on the Environmental profile of North West Frontier Province Pakistan concluded, "the management of protected forests is highly unsustainable. The local people contest the ownership of the forests. They do not allow the FD to plant areas from where mature trees are removed. And natural regeneration fails to get established because of ubiquitous grazing. The forests are not demarcated and the local people promptly appropriate any sizable opening in the forests for cultivation. The law and order situation in many of the forest is tenuous" [Van Dijk and Hussein (1994), p. 41].

Khattak (1994) on the situation of Protected Forests writes "the inability of the government to conduct settlement proceedings in the protected forests is a major cause of forest depletion in the Malakand Civil Division. Even though government claims ownership of these forests, the people do not recognise such ownership. Because the locals have not allowed the settlement process, it has not so far been possible to declare the forests as 'Reserved', to determine the rights of people in them, and to demarcate them. This scenario encourages the pernicious practice of illicit felling of trees to extend agricultural encroachments within forests. Even when trees are felled under the authority of the FD, the local people generally do not allow them to plant up the felled tree areas in the fear that such planting would reinforce the claims of the government to the ownership of the forests" [Khattak (1994), p. 29].

A related problem, to forest degradation, is the opening up of land for cultivation. The forestry legislation prohibits the clearing and breaking up and cultivation of land in such forests (Forest Act of 1927, section 33g). Khattak (1994) notes, "it is not possible to enforce this prohibition under the current law and order situation. Consequently, most forest openings which can sustain agriculture are usually cropped" [Khattak (1994), p. 36]. 
Uncontrolled grazing is yet another problem contributing to the decline of forest by hindering regeneration. "The greatest single factor vitiating the effectiveness of massive efforts at regenerating forests and planting forest lands has been continuous uncontrolled grazing and lack of cooperation and often open hostility from the local people in this venture. Livestock roam free all over the forests...Where expensive fencing is installed, it cannot be effectively maintained against the will of the local communities. And even an army of forest guards cannot protect planted seedling from being surreptitiously uprooted by grazers from the areas which they consider their legitimate grazing grounds. It is not surprising therefore that the average survival of planted seedlings is low and our natural regeneration has seldom succeeded unless we were able to secure the prior cooperation of the local communities, for example in the Germanassisted Kaghan Intensive Forestry Project" [Khattak (1996), p. 4].

The government confesses that the issue of rights is very important, and that not much has been done in regards to the issue of tree tenure in Pakistan. However, "rights have multiplied beyond the carrying capacity of the forests, these have already finished some good forests and are a threat to others. Rights are often misused" [Ashraf (1992a), p. viii].

Ashraf (1992a) in his study on the issue of tenure and legislation (as background study for the FSMP) writes, "The issue of rights of people on communal and public forest is a difficult one. Many right holders feel uncertain about the continuation of their rights and concessions. The reasons are a) repeated declaration by the government of its intention to forfeit the rights; b) informal and wrong seizure of parts of communal forest land by the influential persons; and c) over use of land and over cutting of trees by a few politically and socially powerful right holders in a manner that others are unable to exercise their rights. Being doubtful of the future, many right holders try to obtain maximum benefits in the present" [Ashraf (1992a), p. 44].

\section{Enforcement Mechanism-Its Problems}

Enforcement mechanisms are required to ensure that property rules are observed, and to ensure protection of property from illegal seizure. As discussed earlier, a proper enforcement mechanism must have the following components: (1) a system to detect that a crime has been committed; (2) a system of penalties to ensure that (a) penalties are imposed; and (b) penalties outweigh benefits from the crime. Does such a system exist in the present case?

In Pakistan, the enforcement mechanism basically relies upon the force of law. The principle legislation in this regard is the Forest Act of 1927. This act consolidated the law relating to forests. Forests of Hazara division, however, are regulated by the Hazara Forest Act 1936.

${ }^{33}$ Ashraf (1992a) Background paper FSMP 1992, Forest Policy, Tenure and Legislation.. 
As the state control of the forests was brought about under the premise of conservation, the legislation that ensued the forest control was designed with this consideration. ${ }^{34}$ The basic purpose of legislation has been to protect the forests from misuse and damage done by either man or animal.

\section{The Forest Act, 1927 (Act No. XVI of 1927)}

The act was promulgated to assist in carrying out the 1894 National Forest Policy objectives. It:

1. Lays down procedures for constituting and managing different kinds of forests like reserved and protected Forests;

2. Provides rules to restrict people's action in and around public and community forests;

3. Prescribes duties of the public and the public servants in relation to forests; and

4. Chalks out penalties for violating rules.

"Providing strong legal support to the public service for conserving and protecting ${ }^{35}$ public forests from human and animal damage has been the key objective of all forest legislation". [Pakistan (1992a), section 4.3.2]. The government considers this legislative support as essential to carry out the objectives of a national forest policy. It is needed to prevent forest fires, control pests and diseases.

"The forest legislation in Pakistan is regulatory and punitive in nature. Basic legislation, primarily regulatory and punitive in nature, does exist to prevent and punish abuse of public forests. In fact forest law has been the main tool in the hands of the forest service to ensure rational behaviour of people towards national forests. Almost exclusive reliance on the force of law has been the strategy to achieve the main policy objective of forest conservancy" [Ashraf (1992a), p. 49].

At present the Forest Officer is the person responsible to protect, rather police, the forests [Pakistan (1992a), section, 4.3.2], and these powers are vested in him under the Forest Act of 1927. Under section 75 of chapter XI of the Forest Act of 1927, "the government may invest any Forest Officer with all or any of the following powers, that is to say: (a) the powers to enter upon any land

\footnotetext{
${ }^{34}$ Khattak (1994) question the fundamental principle behind this legislation. He writes "the need for forestry legislation arose towards the close of the nineteenth century to stem the tide of deforestation which was sweeping pre-partition India in response to a high demand for timber created by the construction of cantonments and railways needed for the consolidation of the British rule. Its principal motivation was to safeguard the best forests in the imperial interest, against damage by the ruled" [Khattak (1994), p. 20].

${ }^{35}$ Law even gives some police responsibilities, including the power to arrest, to forest officers.
} 
and to survey, demarcate and map the same; (b) the powers of civil court to compel the attendance of the accused and witnesses and the production of documents and material objects; (c) power to issue a search warrant under the Code of Criminal Procedure, 1898; (d) power to hold an inquiry into the forest offences, and ... to receive and record evidence; and (e) power of a Magistrate to try forest offence cases summarily...; (f) power of a court to order ejectment of a person who has been convicted of an offence, ${ }_{6}$ or to remove or demolish all encroachments made by him" Pakistan Forest Act (1927).

In addition, Section 82 of 1927 Act makes every person living near the forest responsible to help in controlling forest fires and prevention of forest offences. “(1) Every person who exercises any right in a reserved or protected forest or in any other forest land under the control of government ... shall be bound to furnish without unnecessary delay to the nearest Forest Officer or Police Officer any information he may possess respecting the commission of, or intention to commit, any forest offence....and shall assist any Forest Officer or Police Officer demanding his aid (a) in preventing the commission in such forest or land of any forest offence; and (b) in discovering and arresting the offender. (2) Any person who, being bound so to do, without lawful excuse fails.... shall be punishable with imprisonment for a term which may extend to one month, or with fine which may extend to two hundred rupees, or with both" Pakistan Forest Act (1927).

Chapter Six of the Forest Act of 1927 details out the penalties and procedures. According to which the government may prescribe, as penalties for the contravention of any rules, imprisonment of a term which may extend to six months, or a fine which may extend to five hundred rupees, or both. Under this rule, any property (all tools, boats, carts, and cattle) that is suspected to be used in commission of a forest crime may be confiscated (Sections 52-55).

\section{The NWFP Hazara Forest Act, 1936}

This act was promulgated to accommodate the wastelands of Hazara division. It chalks out rules for the management of reserved (Chapter II) and guzara (Chapter III) forests in the division. Chapter VII details out penalties and procedures. These penalties and procedures are the same as specified in the Pakistan Forest Act of 1927.

In addition to these, General Pakistan's law applies to forests. For example, theft of forest produce can be dealt with under Pakistan Penal Code as

${ }^{36}$ Details of what constitute a crime are spelled out in section 26 , clause (h) of sub-section (1), and in section 34. In nutshell these include clearing of land for cultivation, setting of fire, trespassing or grazing cattle, damage to trees, removing any forest produce, hunting, operating mechanical device to cut trees. Nothing in this section prohibits exercise of the rights granted to the local population.

${ }^{37}$ District at that time. 
that of any other property. In sum, the protection of forests relies on the force of law, with major responsibility of enforcement of law lying with the Forest Officer. In addition, local population is required to assist Forest Officer in any operation that is required in this regard. In the next section we see how this mechanism has worked.

\section{Forest Legislation-Its Effectiveness}

We first see how government looks at the current legislation, whether it considers it to be effective under current socio-economic conditions. The FSMP claims that the legislation has proved of great value in conserving public forests. The general view is that the existing legislation is adequate for the management of state forests. However it needs some revisions to allow for community participation in the management affairs. On the issue of customary rights it contends, "the law clearly recognises and accepts the various rights of the people on forests and has set definite rule for their exercise. It thus, helped in keeping peace and order in the village communities. Without such legal authority and clear cut demarcation of areas for the exercise of rights there would have been a chaos and the resource itself would have suffered a quick destruction" [Pakistan (1992a), section 4.3.2].

However, a review of the law and order situation reveals that this is not the case. The law and order situation in the Protected Forests, which constitute majority of the forests, is tenuous. In the previous section we talked about the conflictual relationship between the FD and the local population, how it has affected the working of the department. We also mentioned that this tension has caused violation of law by the locals in retaliation. Cernea (1988a) quotes the number of reported forest cases stands at 50,000 in the Azad Kashmir region, almost one family in every six being involved [Cernea (1988a), p. 140]. This does not take account of those crimes that go unreported.

In fact legislation has lost much of its power. People are no more willing to accept any harsh legal restrictions. "Enforcement of forest laws and rules has become a problem" [Ashraf (1992a), p. 72, emphasis added].

On this Khattak writes "occasionally the people have rebelled even against the solitary restriction: large scale commercial felling. Because such instances posed serious political considerations, they were compromised in various ways, without the use of any legal sanctions" [Khattak (1994), p. 36].

Forest crimes are difficult to detect. The Law relies on the Forest Officer and the locals in detecting crimes. Khattak writes, "The territorial sizes are so large that it is impossible for the official responsible to ensure their sustainable

\footnotetext{
${ }^{38}$ However, it admits that it has caused annoyance to the public. "Uncompromising and harsh application of the Act's provisions and rules has been the main cause of people's antagonism towards FD" [Pakistan (1992a), section, 4.3.1].
} 
management" [Khattak (1994), p. 12]. Pakistan (1992a) also identifies extremely large territorial charges as a problem in the management of forests. This, as a result, makes detection of crimes difficult for them.

The law holds local population responsible in assisting the Forest Officer in crime detection and prevention. They could have been of great value in this regard, but in a situation where the local population stands in open hostility with the FD, and their lack of cooperation towards the FD is a well cited and known phenomenon, it is highly unlikely that they will extend any kind of cooperation in crime detection, and history has not proved otherwise.

\section{Forest Crime Penalties}

Chapter six of the Forest Act of 1927 prescribes penalties for the contravention of any rule. According to it the government may prescribe, as penalties for the contravention of any rules, imprisonment of a term which may extend to six months, or a fine which may extend to five hundred rupees, or both. Under this rule, any property (all tools, boats, carts, and cattle) that is suspected to be used in commission of a forest crime may be confiscated [Pakistan Forest Act (1927), sections 52-55].

"The punishment provided for forest offences remain unchanged since the first version of the Indian Forest Act was promulgated in 1865, while the profitability of illicit trade in timber has increased 500 times. Considering the difficulties in the way of proving guilt in forest offences, and the low punishment provided in the forest laws, they no longer act as effective deterrents to the commission of forest offences" [Khattak (1994), p. 21].

Writing on the enforcement of forestry legislation Ashraf (1992a) concludes, "the effectiveness of forest law is further undermined by the two other factors. First, forest law matters are held in comparatively low esteem by the magistracy and other law enforcing agencies. As a result forest cases are given low priority and kept pending and undecided for long. Huge files of pending cases have accumulated in each province giving the impression to the offenders that nothing was going to happen to them. Second, some forest personnel invested with authority to book arrest and compound the forest cases misuse these powers. It invites public contempt of the law and instigates them to violate the law in protest, often without punishment" [Ashraf (1992a), p. 72].

Pakistan (1992a) observes that many forestry laws have lost their purpose and usefulness. Some others clash with non-forestry legislation, like laws on mines and minerals; and corporate laws on regional development. This causes local and inter-departmental conflicts [Pakistan (1992a), section 4.3.3].

Khattak (1994) brings out an important point that the legislation says nothing about the obligations of the government, and provides no mechanism for remedial action when forest depletion is the result of its own action [Khattak (1994), p. 21]. 
From the above discussion, we can conclude that enforcement of forestry legislation has not been effective and as such has not ensured an orderly behaviour of the human population towards these forests.

\section{Management System}

Crucial for the conservation is a proper management system, which should ensure a continuous flow of services from the resource without harming it. In Pakistan, natural hill forests serve two important functions; (1) protect the watersheds; and (2) are a prime source of timber. Therefore, the management system should be such as to ensure that these forests continue to perform these two vital functions. Indeed, according to the documents of the FD, such system has been developed, presumably practiced as well. These forests are managed under a system of sustained yield principle, based on a selection system. Theoretically, Sustained yield principle ensures that only the annual yield is taken from the forests, without harming the stock which as a result is kept intact. Selection system evolved out of necessity as a permanent cover had to be kept on the steep slopes. From here we can conclude that the system that was developed does indeed suit the objectives. Let us see how thing are done in reality.

In the current organisational set up FD marks trees to be felled, the harvesting, transportation and sale is the responsibility of an autonomous government organisation, FDC (Forest Development corporation). 3 The FDC works in the reserved and protected forests. ${ }^{40}$ Before 1973, FD used to sell standing volume of trees to private contractors, who were then responsible for felling and transporting the timber to the sale depots. Since these contractors were the owners of trees once these were sold out to them, they had an interest in felling much more than that permitted on a sustainable yield basis. The practice got defamed and was eventually stopped. A Forest Development Corporation was then created in the province of NWFP for harvesting, transportation and sale of timber. It tenders out the service of felling and transportation to the private contractor. This practice differed from the earlier practice in the way that under this new arrangement the contractor does not become the owner of the trees at any moment in time. Therefore it was assumed that he would have no incentive to fell more tree than those marked. An assumption that soon proved to be wrong.

This arrangement was adopted to counter the practice of over felling. Indeed, the GOP is satisfied that the FDC has put an end to over felling and "these arrangements have effectively removed corruption that was common under the previous system of stumpage sale to contractors [Pakistan (1992a), section 4.4.4,)." Other authors do not seem to be in agreement [See Khattak (1996, 1994); Khan and Zurflueh (1994)].

\footnotetext{
${ }^{39}$ The FDC operates only in the Province of NWFP.

${ }^{40}$ In the protected forests local people are entitled to a 60 percent share in the sale proceeds.
} 
A report by the Kalam Integrated Development Project (KIDP) identifies 'the alleged collusion' between foresters and contractors, a legacy of British administration, ${ }^{-1}$ still exists in the NWFP forestry department. "Especially poignant is ...(the) observation on the 'alleged collusion' between foresters and contractors. The government of NWFP took action against this in 1973, and disallowed the sale of standing trees to contractors or forest lessees. Later, in 1977, the FDC was created to act in the place of contractors. The overall situation, however, is said to have changed for the worse through the complex series of developments" [Khan and Zurflueh (1994), p. 2].

The report describes the series of events as follows. In 1981, the FDC adopted a system of pre-fixed rates for the payment of royalty. Under this system, the concessionists were paid royalty according to the pre-determined rates 2 that were agreed upon by all the parties. The system functioned well until the late 1980s, because FDC contracted out harvesting and transportation to labour contractors, who had no vested interest in over felling. The labour contractors made profits purely by working efficiently. The surplus revenue accrued to the government.

In the late 1980s, when timber prices rose dramatically, and the labour wages followed suit, a system of net sale was adopted. Under this system FDC deducts the actual harvesting cost plus taxes from the sale proceeds after auction, the remainder was split between the concessionists (60 percent), and the government (40 percent). This allowed more revenue to accrue to concessionists.

"Contractors and (ex) forest lessees were quick to take advantage. Royalty purchasers entered as de facto contractors largely through the ignorance of illiterate majority of concessionists. This was easy. The new net sale was poorly understood by rural concessionists, and the purchasers guaranteed a fixed rate for standing volume of timber... Rather than to face the uncertainties of a perceived fluctuating market and uncertain tenure, concessionists opted for a fixed (low) rate. Royalties were purchased through influencing tribal elders, who entered into legal agreements on behalf of the tribe. Purchasers then registered their or relatives name as contractors with the FDC, and manipulated, the bidding to win the contract (emphasis added), at rates that no contractors not backed by a royalty purchase could compete with. Thus, they entered the same harvesting coupes as contractors that they had purchased." [Khan and Zurflueh (1994), pp. 2-3].

\footnotetext{
${ }^{41}$ Tucker (1982) identified the malpractice in the forestry administration in the colonial regime. He reports of private contractors and forester collusion in timber theft, and how "senior officials of FD were never able to effectively monitor their chronically underpaid subordinates" [Tucker (1982); Khan and Zurflueh (1994)].

${ }^{42}$ Implied rate per tree removed.
} 
They now have enormous interest in over felling, thus realising huge profits. The practice still continues. Although the FDC was established to eliminate the malpractice of forest contractors, it came to depend upon the same contractors. Thus, the same situation of a close relationship between the FDC and contractors came to prevail [ibid, p. 5].

In a report on the environmental profile of the NWFP region (a joint study by the GOP and the Dutch government) also identified the current practice "The forest operation contractors engaged by the FDC for felling and transportation, have purchased the 60 percent share of the people in the sale proceeds, by making advance payments to them, and have therefore regained an interest in illicit felling thereby undermining the raison-de-ere for the establishment of the corporation" [Van Dijk and Hussein (1994), p. 41]. It further writes "The forest department gives high priority to forest conservation, but despite all efforts, the tremendous pressure on forests caused by high prices of timber and the demand for fuelwood and money makes it extremely difficult to save the forest. It is generally perceived that Forest Department Staff is also a threat to the forest" [ibid, p. 41].

Even if all was going well with the harvesting operations, the yield prescriptions in some instances have been too high, endangering the survival of forests. A GTZ (1990) study of Siran and Agror Tanawal Forest Divisions noted that the prescribed yield in some of the working plans are far beyond the sustainable level and would ultimately cause the demise of the forests. Apart from an annual off take which is higher than the annual growth of the forests, regeneration is visibly absent over most forests [Khattak (1994), p. 10].

\section{Political Influences}

Political factors are said to have affected the working of the FD, and have interfered with the management practices. Various studies have talked about the use of political power to further the interest. "Powerful political elements are involved in forestry. Forests have also been frequently used for political patronage. With increasing political uncertainty, FD has been highly politicised" [Khattak (1994), p. 12], with serious repercussions on its functioning.

Cernea (1990) talks about the use of political power by big land owners in the Azad Kashmir Hill Farming Project, namely to have their lands reforested at the expense of the government, whereas the project was suppose to benefit the small land owners. He also mentions how this power has been used to encroach communal lands and incorporate them in private property. Khattak (1994) notes that "the dangerous trend of changing working plan prescription to suite influential political parties still continues" [Khattak (1994), p. 21].

Felling schedules are often changed through the use of political influence to suit the interest of private contractors. They find out which forests are due for 
felling and then approach the locals who are 60 percent owner of the revenues, to buy their shares [Khattak (1994), p. 27].

\section{Accountability}

In the theoretical chapter it was argued that under state management, the state apparatus functions as the custodian of the interest of the public at large, and should discharge its functions accordingly. As such they should be held accountable to the public for their actions. This necessitates a system of accountability.

Does such a system exist in the present set up of forest management in Pakistan? Unfortunately not! The present body of legislation details out prohibited actions, and penalties in case of violation, to safeguard the forests from the misuse by the 'public' but is silent on what ought to be done if the harm is done by the forest officials themselves. Khattak (1994) points out the lack of accountability in the current procedures, he notes that the law "says nothing about the obligations of the government; and provide no mechanism for remedial actions when forest depletion is the result of its own action" [Khattak (1994), p. 21].

Pakistan (1992a), on the issue of forestry legislation and its weaknesses writes "All forestry laws have been made for administrative rather than for technical management of forests. No law provide for legal safeguards against over-exploitation of forests" [Pakistan (1992a), section 4.3.2]. The Modal Forest Law, which is merely an extension of 1927 Act, does not come up with any solution and does not contain any clause on the issue of accountability. Ironically the only clause, section 77 of Chapter XI, 3 that is contained on the conduct of Forest Officers reads, "No suit shall lie against any public servant for anything done by him in good faith under this act" [Pakistan (1992a), appendix 1].

This is despite the fact that the government has admitted, in its own publications, the presence of corruption in forest management as a problem. "In general, the personnel are mismanaged due to excessive political interference in the institutional and administrative matters. Service morale is low, it also suffers from all the ills of professional ethics for which the bureaucracies of developing countries are known for" [Ashraf (1992b), p. 4].

\section{CONCLUDING OBSERVATIONS}

In winding up the discussion we make note of the weaknesses that our analysis has identified. Our first observation is on the issue of ownership. We noted that conflicts over ownership emerged when the state tried to impose its control over the forests. The act itself, and the process afterwards, resulted in a

\footnotetext{
${ }^{43}$ This chapter deals with the duties and powers of the Forest Officers. According to section 76, all Forest Officers are considered public servants.
} 
situation where locals were in open conflict with the government, an uncertain tenure situation emerged from this process in the Protected Forests category.

On the issue of enforcement we noticed many gaps in the present system. Our first observation was about the lack of interest and efforts by the government in the initial enforcement of its control, particularly visible in the task of demarcation of the forests. Secondly, the present enforcement system, which is designed to protect forests from harm done by either man or his animal, is a far cry from a well functioning system. We concluded that it is very close to being non-functional, and hence ineffective.

The analysis of the management system identified significant malpractices; corruption and political interferences were mentioned in this regard. Particularly, there is no system to hold the forest officials answerable to the public, with the result that the officials follow their own interests, to the utter neglect of the 'collective interest'.

As a consequence of all these gaps in the institutional arrangement, the behavioural patterns that have evolved over time, and have come to prevail treat forests as 'no-man's land'. On part of the locals, their initial resentment of the act that alienated them from 'their' resource, and the ensuing uncertainty about the continuation of whatever rights they were left with, the overexploitation of the resource by the government itself for its commercial purposes, and more importantly, the lack of any proper enforcement mechanism, all combined and worked to shape their behaviour such that they consider it justified to extract their share from the resource; hence becoming part in the deforestation process.

For the other two actors, namely the forest officials and the contractors, on account of forests not being their property, it is obvious that they will have little interest in the conservation of the resource. Unless they are forced to do so by being held responsible and answerable to the public. In the absence of any such threat of being questioned for their activities, their 'rational motives' forced them to overexploit the forests.

Unfortunately, the set up, which should have provided an atmosphere that is conducive for the conservation of forests, worked opposite. There is no reason to believe that these actors will change their attitude towards forests if the existing arrangement continues to prevail. If government is serious about conserving the forests, a change in the institutional set up is needed. We quote Bromley and Cernea (1989) on the efficacy of state regime, "most state property regimes are examples of the state's 'reach exceeding its grasp'. Many states have taken on far more resource management authority than they can be expected to carry out effectively. More critically, it sets the government against the peasant when, in fact, successful resource management requires the opposite" [Bromley and Cernea (1989), p. 25]. 


\section{IMPLICATIONS FOR FUTURE FOREST MANAGEMENT}

The first suggestion concerns the ownership issue. The government must take steps to resolve this issue. The way out of this dilemma is to recognise the rights of the locals, and hence create a vested interest of the community in the protection and conservation of forests. We can gain insight from the case of Chaprote forest, 4 where a village committee, in recognition of their traditional rights, was first merely involved in the management of forest and later on given complete charge of the forest. Mumtaz and Nayab (1992) report that the committee was successful in putting a check on the deforestation process.

Second point deals with the involvement of the community in the management affairs. The government considers public participation to be an important item on its agenda. ${ }^{5}$ But it limits the role of local population to plantation activities. If government is serious about harnessing the human resources of the area, then the participation should go beyond what is prescribed in the plan. More specifically, locals should be involved, rather made responsible for establishing an effective monitoring system. ${ }^{-6}$ As Seabright (1993) writes, locals may not have superior monitoring abilities vis-à-vis the state-the latter may be able to call up more sophisticated monitoring technologies—but they have more interest in the protection of the resource. This point is further strengthened by the fact that the sector is facing a financial crunch, and above that human resource problem as indicated in the plan. The government is not in a position to incur huge costs on reinforcing its monitoring system.

The third point relates to accountability. Forest officials should be made accountable and answerable to the public. An interesting example of this comes from the Kalam Integrated Development Project (KIDP). The KIDP supported working plan for the Bahrain area makes it compulsory for the FD to explain its silviculture rationale and marking system to the village community before it commences its operation. Moreover, changes have to be made in the legislation to make officials accountable to the general public.

The state of affairs that emerges out of these suggestions can best be described as 'collective management'. ${ }^{7}$ Collective management has been used to

\footnotetext{
${ }^{44}$ Chaprote forest is situated in the Nagar Valley of the Gilgit district in the Northern Areas. See Mumtaz, et al. (1993) and Mumtaz and Nayab (1992, 1991).

${ }^{45}$ See Forestry Sector Master Plan (1992).

${ }^{46}$ See Poffenberger (1995) for a successful experience with forest protection committees, formed of local tribal population, in the Jungle Mahals of West Bengal. He writes that the emergence of these committees is grounded in tribal resistance movements against state control. A situation closer to what exists in Pakistan.

${ }^{47}$ Other term used to denote this practice is co management. McCay and Acheson (1987) write that it signifies the political claim of local communities to the right to share management power and responsibility with the state. "It is an attempt to formalize a de facto situation to mutual dependence and interaction in resource management [McCay and Acheson (1987), pp. 31-32].
} 
identify a great variety of institutional set up including different combinations on the scale from self-management to state management [Sagdahl (1992), Benjaminsen (1995), pp. 11-12]. However, It is usually taken to mean shared responsibility of management among different parties. ${ }^{-1}$ Ideally, the nature of the responsibility is decided according to the comparative advantage of the party. It is obvious that the sustainability of such a collective management system requires, as a prerequisite, the presence of a local level institution ${ }^{49}$-a suggestion much voiced by the academia! And definitely worth attention in the present case as well!

\section{REFERENCES}

Ashraf, M. (1992a) Forest Policy, Tenure, and Legislation. Background Paper for Forestry Sector Master Plan of Pakistan. Government of Pakistan, Islamabad.

Ashraf, M. (1992b) Forestry Institutions in Pakistan. Background Paper for Forestry Sector Master Plan of Pakistan. Government of Pakistan, Islamabad.

Azhar, R. A. (1993) Commons, Regulations, and Rent-seeking Behaviour: The Dilemma of Pakistan's Guzara Forests. Economic Development and Cultural Change 42:19 115-129.

Banuri, T., and F. A. Marglin (eds) (1993) Who Will Save the Forests? Knowledge, Power and Environmental Destruction. London: Zed Books.

Barzel, Y. (1989) Economic Analysis of Property Rights. Cambridge: Cambridge University Press.

Benjaminsen, T. A. (1995) Natural Resource Management and Decentralisation. Towards Co-management in Mali. Centre for Development and the Environment (SUM), University of Oslo. (Working Paper 3.)

Bromley, D. W., and M. Cernea (1989) The Management of Common Property Resources: Some Conceptual and Operational Fallacies. The World Bank, Washington, D. C. (World Bank Discussion Papers No. 57.)

Cernea, M. M. (1988a) Land Tenure Systems and Social Implications of Forestry Development Programmes (Pakistan). In L. Fortmann and J. W. Bruce (eds) Whose Trees? Propriety Dimensions of Forestry. Boulder and London: Westview Press. 139-148.

Cernea, M. M. (1988b) Alternative Social Forestry Development Strategies. In J. Ives and D. C. Pitt (eds) Deforestation: Social Dynamics in Watersheds and Mountain Ecosystems. London: Routledge. 159-190.

\footnotetext{
${ }^{48}$ Seabright (1993) writes, "All forms of collective management involve some asymmetry in the degree of involvement of different parties. At one end of the spectrum is the practice of delegating managerial responsibility to an agent charged with managing the asset on behalf of others; at the other, full participatory decision making" [Seabright (1993), p. 130].

${ }^{49}$ Basically to provide an authoritative system.
} 
Cernea, M. M. (1990) User Groups as Producers in Participatory Afforestation Strategies. The World Bank, Washington, D. C. (World Bank Discussion Paper No. 70.)

Dani, A. A., C. J. N. Gibbs, and D. Bromley (1987) Institutional Development for Local Management of Rural Resources. East-West Center, Honolulu, Hawaii. (Working Report No 2.)

Demsetz, H. (1967) Towards a Theory of Property Rights. American Economic Review 57: May 347-359.

Dove, M. (1994) Jungle in Nature and Culture. In R. Guha (ed.) Social Ecology. Delhi: Oxford University Press. 90-111.

Eggertsson, T. (1990) Economic Behaviour and Institutions. New York: Cambridge University Press.

FAO (1995) Forestry: Statistics Today For Tomorrow, 1945-1993 ...2010. FAO, Rome.

FAO (1998) Update 33: Asia and The Pacific, National Forest Programmes. FAO, Rome. (RAP Publication 1998/13.)

Fortmann, L., and J. W. Bruce (eds) (1988) Whose Trees? Propriety Dimensions of Forestry. Boulder, London: Westview Press.

Gadgil, M., and R. Guha (1995) Ecology and Equity-The Use and Abuse of Nature in Contemporary India. London: Routledge.

Guha, R. (1989) The Unquiet Woods: Ecological Change and Peasant Resistance in the Himalaya. Delhi: Oxford University Press.

Guha, R. (1993) The Malign Encounter: The Chipko Movement and Competing Visions of Nature. In T. Banuri and F. A. Marglin (eds) Who Will Save the Forests? Knowledge, Power and Environmental Destruction. London: Zed Books. 80-109.

Hanna, S., and M. Munasinghe (eds) (1995) Property Rights and the Environment: Social and Ecological Issues. Washington, D. C.: The World Bank.

Harriss, J., J. Hunter, and C. M. Lewis (eds) (1995) The New Institutional Economics and Third World Development. London: Routledge.

Ives, J., and D. C. Pitt (eds) (1988) Deforestation: Social Dynamics in Watersheds and Mountain Ecosystems. London: Routledge.

Khan, J., and R. Zurflueh (1994) The Timber Harvesting Ban and Its Implications. Kalam Integrated Development Project, Kalam, Pakistan.

Khan, M. (1995) State Failure in Weak States: A Critique of New Institutionalist Explanations. In J. Harriss, J. Hunter, and C. M. Lewis (eds) The New Institutionalist Economics and The Third World Developemnt. London: Routledge.

Khattak, G. M. (1994) Strategy for the Sustainable Development of Forestry in NWFP. IUCN, Peshawar, Pakistan. 
Khattak, G. M. (1996) Proposed Forestry Policy for NWFP. Islamabad, Pakistan. (Paper Presented at Sustainable Development Policy Institute.)

Knudsen, A. J. (1996) Deforestation and Entrepreneurship in the NWFP, Pakistan. Chr. Michelsen Institute (CMI) of Development Studies and Human Rights, Bergen. (CMI Working Paper WP 1996:11.)

Macpherson, C. B. (ed.) (1978) Property: Mainstream and Critical Positions. Oxford: Basil Blackwell.

McCay, B. J., and J. M. Acheson (eds) (1987) The Question of the Commons: The Culture and Ecology of Communal Resources. Tucson, Arizona: The University of Arizona Press.

Mumtaz, S., and Durr-e-Nayab (1991) Management Arrangements of the Chaprote Forest and Their Implications for Sustainable Development. The Pakistan Development Review 30:4 1075-1086.

Mumtaz, S., and Durr-e-Nayab (1992) The Rationale of Common Property in the Development Context. The Pakistan Development Review 31:3 259-285.

Mumtaz, S., et al. (1993) Development and the Local Context: A Case Study of the Chalt-Chaprote Community in the Nagar Valley of Northern Pakistan. Pakistan Office of German Friedrich Ebert Stiftung, Islamabad.

Nabli, M. K., and J. B. Nugent (1989) The New Institutional Economics and its Applicability to Development. World Development 17:9 1333-1347.

North, D. C. (1990) Institutions, Institutional Change and Economic Performance. New York: Cambridge University Press.

North, D. C. (1991) Institutions. Journal of Economic Perspectives 5:1 97-112.

NWFP, Government of (1999) Annual Development Statistics. Bureau of Statistics NWFP, Peshawar.

Ostrom, E. (1990) Governing the Commons: Evolution of Institutions for Collective Action. Cambridge: Cambridge University Press.

Ostrom, E., and R. Gardner (1993) Coping with Asymmetries in the Commons: Self Governing Irrigation Systems Can Work. Journal of Economic Perspectives 7:4 93-112.

Pakistan, Government of 1992c) National Conservation Strategy. Government of Pakistan and IUCN, Karachi.

Pakistan, Government of (1963) The West Pakistan Forest Manual, Volume 1, Legislation Relating to Forest Administration with Rules Made Under Forest Acts and Regulations. Government of Pakistan, Peshawar

Pakistan, Government of (1992a) Forestry Sector Master Plan: National Perspective. Islamabad.

Pakistan, Government of (1992b) Forestry Sector Master Plan: North West Frontier Province. Islamabad.

Pakistan, Government of (1998) Compendium on Environment Statistics Pakistan. Federal Bureau of Statistics, Islamabad. 
Pakistan, Government of (1999-2000) The Economic Survey. Finance Division, Islamabad.

Pejovich, S. (1990) The Economics of Property Rights: Towards a Theory of Comparative Systems. Dordrecht: Kluwer Academic Publishers.

Poffenberger, M. (1995) The Resurgence of Community Forest Management in the Jungle Mahals of West Bengal. In D. Arnold, and R. Guha (eds) Nature, Culture, Imperialism-Essays on the Environmental History of South Asia. Delhi: Oxford University Press. 336-369

Reeve, A. (1986) Property, Issues in Political Theory Series. Basingstoke: Macmillan.

Runge, C. F. (1984) Strategic Independence in the Model of Property Rights. American Journal of Agricultural Economics 66: 807-813.

Seabright, P. (1993) Managing Local Commons: Theoretical Issues in Incentive Design. Journal of Economic Perspectives 7:4 113-134.

Singh, C. (1986) Common Property and Common Poverty: India's forests, Forest dwellers, and the Law. Delhi: Oxford University Press.

Tietenberg, T. (1992) Environmental and Natural Resource Economics. New York: Harper Collins.

Tietenberg, T. (1994) Environmental Economics and Policy. New York: Harper Collins College.

Tisdell, C. (1993) Environmental Economics: Policies for Environmental Management and Sustainable Development. Aldershot: Edward Elgar.

Van Dijk, A., and M. Hussein (eds) (1994) Environmental Profile of the North West Frontier Province Pakistan. Rawalpindi: Imprint.

Waldron, J. (1990) The Right to Private Property. Oxford: Clarendon Press. 


\begin{abstract}
This study analyses the institutional set-up of forest management in Pakistan, focusing on the North West Frontier Province, which houses 40 percent of the total forestlands. These areas have faced significant deforestation in the past. It is feared that if nothing is done to check this process, these forests will soon disappear. The study argues for the Property Rights School of thought that the roots of environmental problems are to be traced to inadequate and illdefined property institutions. The study develops a normative criterion, describing the conditions that are essential for optimal utilisation and conservation of a resource, to be used in assessing the present situation. The analysis indicates that there are problems in the ownership structure, in the enforcement of property rules, as well as in the management system. It is concluded that the present institutional set-up is inappropriate to achieve the objective of forest conservation, and changes in this set-up are suggested. The study puts forward 'collective management' as an alternative institutional set-up.
\end{abstract}

